\title{
Resolusi Konflik Sosial melalui Pendekatan Komunikasi di Lingkungan Monjok dan Karang Taliwang Kota Mataram
}

\author{
Siti Nurul Yaqinah \\ UIN Mataram \\ e-mail: sitinurulyaqinah@yahoo.co.id
}

\begin{abstract}
Abstrak
Konflik adalah salah satu fenomena yang terjadi sebagai bagian dari dinamika masyarakat. Di antara konflik sosial yang mengakar kuat di komunitas kota Mataram adalah konflik Monjok dan Karang Taliwang. Oleh karena itu, penelitian ini bertujuan untuk mengetahui latar belakang terjadinya konflik sosial, dampak konflik terhadap kehidupan masyarakat dan komunikasi dalam upaya mendekati penyelesaian konflik di lingkungan Monjok dan Karang Taliwang. Penelitian ini menggunakan metode deskriptif kualitatif, data diperoleh melalui wawancara, observasi dan dokumentasi. Analisis yang digunakan adalah reduksi data, penyajian data, dan penarikan kesimpulan. Untuk menguji validitas data, para peneliti melakukan penelitian, triangulasi waktu ekstra metode dan sumber, dan pemeriksaan terkait. Hasil yang diperoleh dalam penelitian ini adalah konflik yang terjadi antara warga Monjok dan Karang Taliwang yang dipicu oleh pemindahan tempat sampah oleh Karang Taliwang yang minim koordinasi dan diseminasi sehingga memicu aksi perusakan yang disebabkan oleh warga Monjok. Pemicu lainnya adalah perselisihan seorang pemuda dan keberadaan pihak ketiga yang memicu situasi untuk transferabilitas. Jadi, dampaknya pada konflik; masyarakat psikologis, komunikasi, dampak ekonomi dan dampak sosial terhenti. Oleh karena itu, beberapa pendekatan yang digunakan dalam menangani pendekatan konflik adalah komunikasi melalui Consolas, pendekatan komunikasi melalui negosiasi atau musyawarah, pendekatan komunikasi melalui mediasi dan pendekatan komunikasi yang melibatkan para pemangku kepentingan.
\end{abstract}

Kata kunci: Resolusi Konflik, Komunikasi Konflik Sosial

\begin{abstract}
The conflict is one of the phenomena that occurs as part of the dynamics of the community. Among the social conflict that rooted strongly in the community of the city of Mataram was the conflict Monjok and Karang Taliwang. Therefore, this research aims to know the background of the occurrence of social conflict, the impact of conflict on the lives of communities and communications in an effort to approach conflict resolution in an environment of Monjok and Karang Taliwang. This research uses a qualitative descriptive method, data obtained through interviews, observation and documentation. The analysis used was the reduction of the data, the presentation of data, and the withdrawal of the conclusion. To test the validity of the data, the researchers conducting the study, extra time triangulation of methods and sources, and the associated examination. The results obtained in this study are a conflict that occurs between the citizens of Monjok and Karang Taliwang triggered by the removal of the trash container by Karang Taliwang minimal coordination and dissemination so as to trigger the action
\end{abstract}


of the destruction caused by the citizens Monjok. Another trigger is a young man's dispute and the existence of a third party that provokes the situation for transferability. So, the impact on the conflict; psychological society, communication, economic impact and stalled social impact. Therefore, some approaches used in handling the conflict approach is communication through Consolas, the communication approach through negotiations or deliberations, approach to communication through mediation and communication approaches involving stakeholders.

Keywords: Conflict Resolution, Social Conflict Communication

\section{PENDAHULUAN}

Konflik adalah satu fenomena yang akan selalu mewarnai interaksi sosial sehari-hari. Manusia sebagai makhluk sosial selalu berinteraksi dengan sesama manusia, ketika berinteraksi dengan sesama manusia selalu diwarnai dua hal, yaitu konflik dan kerja sama. Situasi dan kondisi tertentu dapat menjadi pemicu konflik, mulai dari ketidakcocokan pribadi, perbedaan sistem nilai, persaingan, ketidakjelasan batas-batas wewenang dan tanggungjawab, perbedaan fungsi, komunikasi yang tidak nyambung, pertentangan kepentingan dan lain-lain. Konflik tersebut ternyata dapat terjadi kapanpun dan dimanapun, seperti halnya konflik yang terjadi di kota Mataram.

Kota Mataram secara geografis, kehidupan sosial dan kebudayaannya memiliki keunikan yang menarik untuk dianalisis, baik dari sisi historis, ekonomi, maupun simbol-simbol sosial lainnya. Salah satunya yakni kondisi kota Mataram yang seringkali mengalami konflik, baik konflik agama maupun konflik sosial yang dilatarbelakangi pemahaman dan perbedaan pandangan antar kelompok masyarakat yang sulit dimaknai dalam konteks rasionalitas. Di antara konflikkonflik sosial yang mengakar secara kuat dalam masyarakat kota Mataram adalah konflik Monjok dan Karang Taliwang.

Pada kasus konflik yang terjadi antara warga Monjok dan Karang Taliwang dipicu oleh pemindahan container sampah yang berada di Karang Taliwang ke tempat pemakaman umum (TPU) warga Monjok yang kebetulan berada di wilayah Karang Taliwang. Keberadaan tempat pembuangan sampah tersebut dinilai mengganggu aktivitas warga sekitar. Tempat pembuangan sampah (TPS) yang sejak awal dihajatkan untuk kepentingan bersama namun minim 
koordinasi dan sosialisasi sehingga memicu aksi pengerusakan oleh warga Monjok. Aksi pengerusakan itupun disambut oleh warga Karang Taliwang dengan merobohkan tembok kuburan yang menjadi tempat pemakaman warga Monjok, kemudian disusul dengan pertikaian fisik yang menimbulkan banyak korban luka. Jika konflik ini dibiarkan dan terjadi dalam waktu yang lama dapat meluas dan melibatkan lebih banyak pihak. Kerugian yang ditimbulkan juga tidak hanya dirasakan oleh pihak-pihak yang berkonflik namun juga dirasakan oleh pihak lain, apalagi wilayah Karang Taliwang merupakan salah satu destinisasi wisata kuliner di kota Mataram, tentu banyak pihak yang dirugikan.

Upaya untuk mencegah terulangnya pertikaian antara warga tersebut, beberapa pihak bekerja sama melakukan berbagai pendekatan langsung pada warga yang berdomisili di daerah sekitar lingkungan Monjok dan Karang Taliwang. Salah satu cara yang dilakukan oleh pihak keamanan terdekat adalah membangun posko keamanan terpadu di antara kedua wilayah yang bertikai untuk menghindari konflik-konflik skala kecil yang berpotensi terjadinya konflik yang lebih besar. Namun berdasarkan pengamatan peneliti di lapangan, penyelesaian konflik warga Monjok dan Karang Taliwang bukan hanya dibutuhkan pendekatan keamanan, tetapi harus terlebih dahulu menggunakan pendekatan komunikasi, karena peran komunikasi di dalam konflik sebenarnya mampu menciptakan banyak manfaat, energi dan solusi.

Komunikasi yang konstruktif diyakini mampu mendorong para pihak yang sedang berkonflik untuk membentuk kekompakan dalam menentukan cara penyelesaian konflik. Persoalannya adalah bagaimana menempatkan komunikasi dan konflik serta cara penyelesaian konflik itu sendiri. Secara komunikasi, konflik dipandang dengan cara lama dan cara baru. Cara lama bermakna buruk, biang masalah (trouble maker), dan harus dihindari. Sementara cara terkini dimaknai tidak selalu buruk, tidak perlu dihindari/harus dihadapi, dapat dikelola secara progresif, bermanfaat jika ditangani dengan benar, serta konflik dapat menstimulasi kreativitas.

Oleh karena itu, kajian dalam penelitian ini lebih terfokus pada pendekatan komunikasi dalam upaya resolusi konflik sosial warga Monjok dan Karang 
Taliwang. Pendekatan komunikasi dimaksudkan untuk merubah opini, sikap dan perilaku berbagai komponen yang terlibat dalam konflik untuk melakukan komunikasi yang intensif dalam suasana kekeluargaan guna mencapai titik kesamaan. Menurut Santoso (2005:158) adanya konflik sosial adalah bukti bahwa ada kemacetan komunikasi antara warga masyarakat. Komunikasi adalah bagian dari proses budaya yang adab, maka komunikasi yang konstruktif dengan berbagai kiat dan pendekatannya diyakini mampu mendorong para pihak yang sedang berkonflik untuk membentuk kekompakan dalam menentukan cara penyelesaian konflik. Saat ini intensitas komunikasi antara berbagai elemen masyarakat di Monjok dan Karang Taliwang dalam rangka menyelesaikan konflik telah dilakukan walaupun hasilnya belum optimal karena masih ada pertentangan pendapat dan keinginan yang belum sejalan, namun telah dicapai kemajuan yang cukup berarti. Hal ini dapat dilihat dengan menurunnya pertikaian yang terjadi.

Untuk itu, melalui penelitian ini, peneliti ingin menemukan tentang bagaimana upaya resolusi konflik melalui pendekatan komunikasi antara warga Monjok dan Karang Taliwang dan fenomena yang terlibat dalam konflik dapat disatukan dalam suatu kesamaan pemahaman, penilaian dan persepsi melalui komunikasi.

\section{PEMBAHASAN}

Untuk mengkaji secara utuh berbagai persoalan yang terkait dengan penelitian ini, peneliti menggunakan paradigma penelitian kualitatif dengan jenis penelitian deskriptif. Penelitian deskriptif adalah jenis penelitian yang bertujuan untuk menggambarkan, meringkaskan berbagai kondisi, berbagai situasi, atau berbagai fenomena realitas sosial yang ada di masyarakat yang menjadi objek penelitian. Paradigma ini sengaja dipilih untuk dapat menemukan makna secara lebih luas (Prasetya, 2007:4).

Sementara data dalam penelitian ini akan difokuskan kepada tiga hal yakni tentang penyebab terjadinya konflik sosial, dampak dan peran komunikasi dalam resolusi konflik warga Monjok dan Karang Taliwang. Pada penelitian kualitatif, sumber data adalah data primer dan data sekunder. Adapun yang menjadi sumber 
data primer dalam penelitian ini adalah tokoh masyarakat formal (pemerintah), tokoh masyarakat informal (tokoh agama, tokoh adat dan para stakeholder) serta masyarakat yang terlibat konflik. Sedangkan sumber data sekunder adalah data penelitian yang diperoleh peneliti secara tidak langsung melalui media perantara, misalnya melalui dokumen-dokumen kepustakaan, kajian-kajian teori dan karya ilmiah yang ada relevansinya dengan masalah yang diteliti.

Untuk mengumpulkan data, peneliti menggunakan metode atau teknik; (1) wawancara mendalam (in-depth intervew). Data ini meliputi, proses komunikasi yang terjadi pada setiap tahap perselisihan yang ada, pada penyebab konflik, dampak konflik dan pada pendekatan komunikasi terkait dengan langkah-langkah apa yang dilakukan dalam upaya resolusi konflik pada warga Monjok dan Karang Taliwang dengan melibatkan tokoh masyarakat formal (pemerintah), tokoh masyarakat informal (tokoh agama, tokoh adat dan para stakeholder) serta masyarakat yang terlibat konflik yang dipilih secara purposive Sampling; (2) observasi langsung (derect observation), Teknik ini digunakan agar peneliti dapat mengamati secara langsung pandangan, persepsi masyarakat tentang penyebab, dampak dan proses resolusi konflik yang terjadi pada lokasi penelitian tersebut; (3) dokumentasi, peneliti mengumpulkan informasi tentang data dan dokumen yang berhubungan dengan hal-hal atau variabel berupa buku-buku, catatancatatan, dan foto-foto, koran atau sumber-sumber tertulis lainnya yang berkaitan dengan konflik sosial yang terjadi di wilayah Monjok dan Karang Taliwang.

Data-data yang telah diperoleh melalui berbagai teknik tersebut di atas, dianalisa dengan metode diskriptif-analitis, artinya, data yang diperoleh dideskripsikan, dianalisis dan ditafsirkan menurut isi. Adapun tenik analisis data dalam penelitian ini berpedoman pada langkah-langkah analisis data penelitian kualitatif yang dikemukakan oleh Miles dan Huberman seperti yang dikutip Sugiyono yaitu, reduksi data, penyajian data dan penarikan kesimpulan (Sugiyono, 2009:249).

Adapun untuk menguji keabsahan data (Sugiyono, 2009:249), peneliti melakukan tiga langkah yaitu: (1) memperpanjang waktu penelitian untuk menemukan data secara utuh (2) triangulasi metode dan sumber dalam rangka 
memastikan data yang terkait dengan tiga fokus kajian tersebut (3) pemeriksaan sejawat melalui diskusi dalam rangka memperkaya dan mendapat masukanmasukan dari para ahli atau kolega sehingga temuan penelitian dapat dipertanggungjawabkan secara ilmiah.

\section{Analisis Latar Belakang Timbulnya Konflik Sosial}

Secara umum konflik sosial dapat terjadi apabila seseorang atau kelompok terhalang upayanya dalam mencapai tujuannya. Hal ini dapat disebabkan karena perbedaan paham terhadap tujuan itu sendiri, niai-nilai sosial, dan norma-norma sosial, maupun terhadap tindakan dalam masyarakat. Terlebih lagi apabila sanksi atas pelanggaran yang terjadi di atas nilai dan norma tidak dilaksanakan dengan adil, maka konflik dapat berubah menjadi tindakan kekerasan. Hendrick mengidentifikasi proses terjadinya konflik terdiri dari tiga tahap: Pertama; peristiwa sehari-hari, peristiwa sehari-hari ditandai dengan adanya individu yang merasa tidak puas dan jengkel terhadap lingkungannya. Perasaan tidak puas kadang-kadang berlalu begitu saja dan muncul kembali saat individu merasakan adanya gangguan. Kedua; adanya tantangan, apabila terjadi masalah individu saling mempertahankan pendapat dan menyalahkan pihak lain. Ketiga; timbulnya pertentangan, pada tahap ini masing-masing individu atau kelompok bertujun untuk menang dan mengalahkan kelompok lain (Wahyudi, (2008:19).

Dalam temuan ini, pemicu konflik yang terjadi antar warga Monjok dan Karang Taliwang karena satu sama lain tidak saling menghargai. Akar masalahnya adalah pemindahan container sampah, di mana kedua belah pihak memiliki pandangan yang berbeda-beda. Berdasarkan pengakuan warga Karang Taliwang bahwa pemindahan container sampah ke tempat pemakaman umum warga Monjok sudah melalui prosedur yang benar, misalnya saja sudah melakukan komunikasi dan koordinasi dengan tokoh masyarakat dan warga Monjok, hanya saja dari hasil komunikasi dan koordinasi tersebut belum ada titik temu, akan tetapi karena keberadaan tempat pembuangan sampah tersebut dinilai mengganggu aktivitas warga sekitar karena bau tidak sedap dari kotoran sampah apalagi wilayah Karang Taliwang merupakan salah satu destinisasi wisata kuliner 
di kota Mataram, di mana tamu-tamu dari luar berdatangan di wilayah tersebut untuk menikmati wisata kuliner, tentu membutuhkan kenyamanan. Tidak elok ketika mereka sedang makan tercium bau tidak sedap.

Selain itu, pemerintah juga sedang menyiapkan program penataan kawasan wisata kuliner di wilayah Karang Taliwang, seperti penataan lampu jalan, pedestrian dan pengelolaan sampah yang menjadi perioritas pemerintah kota Mataram, maka tempat pembuangan sampah (TPS) yang sejak awal dihajatkan untuk kepentingan bersama tersebut dipindahkan di dekat pemakaman umum warga Monjok yang masih diklaim berada di wilayah Karang Taliwang.

Di sisi lain, warga Monjok mengklaim bahwa pemindahan tempat pembuangan sampah (TPS) minim koordinasi dan sosialisasi, sebagaimana penuturan kepala lingkungan Monjok Culik berikut ini:

Secara garis administrasi keberadaan pemakaman warga Monjok sudah menjadi bagian dari wilayah Monjok. Kami merasa tidak diajak bicara oleh warga Karang Taliwang, kami hanya didatangi oleh salah seorang anggota dewan dari Hanura, tetapi itu tidak menyelesaikan masalah, karena dia datang bukan dengan cara persuasif tetapi dengan cara memaksa dan marah-marah agar kami menerima proses perpindahan tersebut. Menurut saya, apa salahnya dikoordinasikan dan dimusyawarahkan dulu dengan kami, jika hasil musyawarah warga Karang Taliwang diberi wewenang untuk memindahkan container dan membuat tempat pembuangan sampah di wilayah kami, kami akan menerima hasil koordinasi tersebut, apalagi niatnya untuk kepentingan bersama, hanya saja harus ada upaya koordinasi dan komunikasi karena ini wilayah kami dan menjadi tanggungjawab kami. Hal inilah yang kemudian memicu aksi pemindahan atau pengerusakan container sampah oleh warga Monjok (wawancara Busyairi, 2018).

Pengerusakan kontainer sampah yang dilakukan warga Monjok kemudian memicu reaksi warga Karang Taliwang membalas dengan merobohkan tembok kuburan yang menjadi tempat pemakaman warga Monjok, akibat pengerusakan tembok kuburan kemudian berlanjut menjadi pertikaian atau perang fisik yang menimbulkan banyak korban luka. Kedua wilayah saling serang di tengah sawah perbatasan dua wilayah dengan menggunakan senjata tajam seperti parang, panah, tombak, senjata rakitan beramunisi kelereng. Sebagian besar warga yang terlibat bentrok adalah pemuda dan pria dewasa. Banyak warga baik dari Monjok maupun Karang Taliwang mengalami luka-luka. 
Seiring waktu, perselisihan antara warga Monjok dan Karang Taliwang dapat diatasi karena kepolisian kota Mataram dan TNI berusaha untuk melerai dan pemerintah kota Mataram segera melakukan mediasi dengan memanggil perwakilan tokoh dari kedua wilayah tersebut. Mediasi tersebut menghasilkan kesepakatan bahwa pemerintah kota Mataram mengambil langkah untuk memindahkan tempat pembuangan sampah yang berada di dekat kuburan warga Monjok dan membangun tempat pembuangan sampah permanen di wilayah yang tidak jauh dari wilayah Karang Taliwang, pemerintah juga berjanji untuk merehabilitasi tembok kuburan warga Monjok yang dirusak oleh warga Karang Taliwang. Konflik akhirnya mereda dan masing-masing pihak sepakat untuk berdamai. Sehingga rentang waktu yang cukup lama tidak lagi terjadi konflik sebagaimana waktu-waktu sebelumnya (wawancara Maslandu, 2018).

Penyelesaian konflik yang dilakukan oleh pemerintah kota Mataram sebagaimana diuraikan di atas, ternyata hanya bersifat sementara saja. Selang beberapa tahun kemudian konflik Monjok dan Karang Taliwang kembali muncul yang dipicu oleh perselisihan anak muda yang sengaja diciptakan untuk memprovokasi keadaan sehingga menimbulkan konflik yang kedua. Anak-anak muda ini saling hujat serta trek-trekan di jalan, karena rasa solidaritas yang kuat, masalah yang pada awalnya bersifat pribadi antara anak-anak muda berkembang menjadi masalah yang melibatkan warga kampung. Hal inilah yang menjadi pemicu munculnya kembali konflik (wawancara Maslandu, 2018).

Informan lain menguraikan bahwa indikasi konflik yang kedua ini terjadi karena ada pihak ketiga yang mencoba memanfaatkan situasi konflik Monjok dan Karang Taliwang untuk pengalihan isu. Lingkungan Karang Bagu yang ada di wilayah Karang Taliwang merupakan wilayah yang dicurigai sering melakukan transaksi jual beli narkoba, sehingga ketika informasi penggerebekan oleh pihak kepolisian terhadap transaksi tersebut, maka mereka mengelabui pihak keamanan dengan memprovokasi masyarakat melalui suara petasan. Kedua kubu tersebut ketika mendengar suara petasan, dianggap sebagai pertanda adanya pihak yang memancing untuk melakukan serangan. Sebenarnya, situasi di kedua lingkungan sudah kondusif dan telah terbina cukup baik, namun karena adanya pihak yang 
tidak bertanggung jawab, sehingga terjadilah konflik yang kedua (wawancara, Wildan, 2018).

Berdasarkan pengamatan peneliti, konflik yang kedua ini cukup lama, kurang lebih tujuh bulan lamanya. Kedua kubu tersebut sudah beberapa kali terlibat ketegangan, dan beberapa kali pula sepakat berdamai yang difasilitasi oleh pemerintah daerah, namun ketegangan kembali terjadi, dua kubu saling serang di daerah perbatasan, jalan menuju arah Karang Taliwang diblokir warga menggunakan ranting pohon dan batu, satu lapak pedagang dibakar warga yang berkonflik, puluhan warga dari kedua kubu mengalami luka akibat terkena lemparan batu dan anak panah, bahkan salah seorang dari warga Monjok meninggal dunia karena terkena anak panah. Aparat gabungan polres Mataram dan Polda NTB serta TNI turut melerai dengan beberapa kali mengeluarkan tembakan peringatan. Aparat kepolisian dan TNI melakukan penjagaan di perbatasan kedua lingkungan tersebut.

Dari data empiris di atas, peneliti menilai, pemindahan container sampah yang menjadi akar masalah jika dilakukan koordinasi dan sosialisasi sejak awal tentu konflik tidak akan terjadi. Temuan ini sejalan dengan pandangan Robbins sebagaimana yang dikutip oleh Sofiyati, konflik muncul karena ada kondisi yang melatarbelakanginya (antecedent conditions). Kondisi tersebut disebut juga sebagai sumber terjadinya konflik, Salah satunya adalah komunikasi (Puput Sofiyati, dkk, 2011:9). Menurutnya, komunikasi yang buruk antar individu, dalam arti perbedaan persepsi atau pandangan terhadap suatu hal, ide, maupun gagasan dalam suatu masyarakat, dapat menjadi sumber konflik. Suatu hasil penelitian menunjukkan bahwa kesulitan semantik, pertukaran informasi yang tidak cukup, dan gangguan dalam saluran komunikasi merupakan penghalang terhadap komunikasi dan dapat menciptakan konflik.

Senada dengan pandangan Robbins di atas, Santoso menilai bahwa adanya konflik sosial adalah bukti bahwa adanya kemacetan komunikasi antara warga masyarakat. Sebagai basis dalam relasi masyarakat, yang hidup dan berkembang atas dasar perbedaan ide, asal usul, latar belakang, dan kebiasaan kehidupan sosial budaya, maka komunikasi sejatinya dimaknai sebagai proses 
pertukaran informasi, gagasan, serta ide baik individu maupun kelompok karena komunikasi membutuhkan feedback yang berjalan secara dinamis.

Sementara Coser menilai terjadinya konflik adalah sebagai tanda bahwa semua hubungan sosial memiliki tingkat antagonisme tertentu, ketegangan, atau perasaan-perasaan negatif lainnya (Johnson, Doyle Paul: 199). Hal ini merupakan akibat dari keinginan individu atau kelompok untuk meningkatkan kesejahteraan, kekuasaan, prestise, dukungan sosial, atau penghargaan lainnya. Sementara itu, masing-masing mereka, secara individual ataupun kelompok, di samping memiliki sejumlah kesamaan, juga mempunyai serangkaian perbedaan. Persamaan dan perbedaan tersebut menyangkut jenis kelamin, tingkat pendidikan, pekerjaan, latar belakang budaya, ideologi, cara pandang, cita-cita, kepentingan, dan sebagainya. Pemikiran dan pendirian yang berbeda itu pada akhirnya akan menghasilkan perbedaan individu yang dapat memicu konflik.

Oleh karena itu, dari keragaman dan perbedaan tersebut, dibutuhkan suatu pendekatan komunikasi yang relevan. Pendekatan komunikasi dimaksudkan untuk merubah opini, sikap dan perilaku berbagai komponen yang terlibat dalam konflik agar melakukan komunikasi yang intensif dalam suasana kekeluargaan guna mencapai titik kesamaan. Tak berlebihan bila para pakar komunikasi kerapkali mengatakan bahwa komunikasi adalah ciri instrinsik yang ada pada manusia yang sekaligus membedakan manusia dari makhluk lain. Proses komunikasi inilah yang selama ini menjadi sarana dan alat manusia menyampaikan pesan, mengelola persoalan dan berbagai problema sosial, membangun ikatan kebersamaan dan sekaligus sebagai pemecah beragam masalah yang disebabkan oleh kesenjangan komunikasi (Jalaluddin Rakhmat, 2001:4).

Namun demikian, konflik antara warga Monjok dan Karang Taliwang sebagaimana diuraikan di atas, kerap hanya dijadikan persoalan sepele ketika persoalan tersebut bisa dikatakan belum berdampak besar pada kondisi masyarakat. Timbulnya korban dari pertikaian tersebut justru baru akan mengundang tindakan pemerintah daerah untuk segera menyelesaikan persoalan. Konflik yang terjadi dalam masyarakat semuanya tidak pernah berdiri sendiri. Apalagi jika konflik seperti yang diuraikan di atas dibiarkan dan terjadi dalam 
waktu yang lama dapat meluas dan melibatkan lebih banyak pihak. Kerugian yang ditimbulkan juga tidak hanya dirasakan oleh pihak-pihak yang berkonflik namun juga dirasakan oleh pihak lain, baik secara langsung maupun secara tidak langsung, apalagi wilayah Karang Taliwang merupakan salah satu destinisasi wisata kuliner di kota Mataram, tentu banyak pihak yang dirugikan.

\section{Analisis Dampak Konflik Sosial}

Konflik akan menimbulkan berbagai macam dampak. Konflik yang sering terjadi ini dapat merugikan individu dan kelompok dalam masyarakat, maka diperlukan penanggulangan oleh pemerintah dan berbagai elemen masyarakat sehingga tidak menyebabkan kerugian, baik secara fisik yang ditandai dengan adanya korban jiwa, psikologis, sosial maupun materil (ekonomi). Berdasarkan temuan peneliti, dampak-dampak konflik sebagai akibat konflik Monjok dan Karang Taliwang adalah sebgai berikut:

\section{Dampak Psikologis}

Setiap individu mempunyai sikap atau sifat pribadi yang berbeda satu sama lainnya. Perbedaan sikap atau sifat ini, akan menentukan bagaimana individu menghadapi konflik yang muncul. Secara psikologis dampak dari pasca konflik akan menimbulkan trauma yang mendalam, prasangka, kecurigaan pada kelompok lain, sehingga ini mempengaruhi interaksi sosial masyarakat. Prasangka merupakan sikap negatif pada seseorang atau sekelompok orang hanya karena orang tersebut merupakan bagian dari kelompok tertentu.

Dalam konteks ini, konflik yang terjadi menimbulkan dampak secara psikologi bagi warga masyarakat, masyarakat yang tadinya biasa sholat subuh di masjid dengan adanya konflik menjadi tidak nyaman dan trauma untuk ke masjid karena ada kekhawatiran terkena panah atau tombak, demikian juga ketika bepergian pada malam hari, masyarakat yang tadinya biasa keluar masuk malam hari menjadi cemas dan khawatir, karena biasanya serangan atau perang itu terjadi mulai malam hari hingga subuh (wawancara, Hasin, 2018). 
Hal senada disampaikan oleh salah seorang informan bahwa konflik menyebabkan trauma yang sangat mendalam bagi masyarakat, misalnya masyarakat Monjok yang biasanya kalau ada orang meninggal setiap subuh selama 9 hari bersama keluarganya membaca yasin di kuburan, tetapi selama konflik terjadi mereka tidak berani lagi melakukan rutinitas tersebut karena takut diserang oleh warga Karang Taliwang. Apalagi konflik yang terjadi ini menimbulkan korban jiwa bagi warga Monjok, sehingga konflik memunculnya sifat egois dan dendam bagi masyarakat. Ada kekhawatiran walaupun konflik sudah berakhir tetapi kalau ingatan konflik tersebut muncul dan kemungkinan akan menjadi benih timbulnya konflik selanjutnya (wawancara, Wildan, 2018).

\section{Dampak Komunikasi Macet}

Komunikasi adalah bagian mutlak dari proses budaya yang adab. Komunikasi merupakan hal sangat penting bagi kehidupan masyarakat. Dalam kehidupan sehari-hari, seseorang tidak bisa terlepas dari komunikasi. Komunikasi adalah pertukaran informasi antara dua orang individu atau lebih yang bertujuan untuk memberi dan menerima informasi. Komunikasi tidak bisa dianggap sepele, karena seringkali komunikasi dapat mengakibatkan konflik antar individu maupun kelompok. Kegagalan berkomunikasi karena dua pihak tidak dapat menyampaikan pikirannya, perasaan dan tindakan sehingga membuka jurang perbedaan informasi di antara mereka dan hal tersebut dapat mengakibatkan konflik. Hal inilah yang terjadi pada warga Monjok dan Karang Taliwang.

Sejak konflik ini muncul, kedua lingkungan enggan untuk saling berkomunikasi, karena merasa dendam dan gengsi atau merasa enggan untuk saling menyapa, mereka menganggap satu pihak berusaha untuk mengatur pihak yang lain sehingga haknya merasa dibatasi dan dilanggar, malah yang terjadi justru komunikasi yang sifat provokatif. Provokasi satu pihak sering menyinggung pihak yang lain dan memanas-manasi pihak lawan sehingga percekcokan atau keributan kembali terjadi (wawancara, Muhammad Husni, 2018).

Salah satu mitos utama yang kebanyakan disandang adalah bahwa komunikasi yang buruk merupakan alasan utama dari konflik-konflik "Seandainya saja kita dapat berkomunikasi satu sama lain, kita dapat menghapus perbedaan- 
perbedaan pendapat kita" (Syafei Ibrahim, 2001). Ungkapan semacam ini bukan tidak masuk akal, bila masing-masing kita diberi waktu untuk berkomunikasi. Tetapi tentu saja, komunikasi yang buruk pastilah bukan sumber dari semua konflik, meskipun ada cukup banyak bukti yang memberi kesan bahwa masalahmasalah dalam proses komunikasi berperan dalam menghalangi kolaborasi dan merangsang kesalapahaman.

Kemacetan komunikasi sebagaimana diuraikan di atas menyebabkan komunikasi tidak efektif. Komunikasi tidak efektif karena kesalapahaman dan ketidakpahaman individu dalam menerima informasi yang diterima. Kesalapahaman tersebut menandakan adanya suatu yang mengganggu, baik dari pesan yang disampaikan maupun semua unsur komunikasi itu sendiri. Efek yang timbul akibat penyampaian suatu pesan dari komunikator kepada komunikan dapat mempengaruhi proses komunikasi, karena melalui kegiatan penyampaian pesan dapat menimbulkan beberapa persepsi terhadap pesan dan komunikator. Persepsi komunikan terhadap pesan (informasi) yang disampaikan oleh komunikator bisa ditafsirkan salah karena berkaitan dengan masalah kepribadian komunikan itu sendiri, termasuk pengalaman dan kondisinya pada saat proses penerimaan pesan berlangsung.

\section{Dampak Ekonomi}

Konflik merupakan suatu fenomena yang terjadi sebagai bagian dari dinamika kehidupan masyarakat. Konflik yang terjadi dalam mayarakat akan menimbulkan berbagai kerugian bagi masyarakat. Konflik yang terjadi antara warga Monjok dan Karang Taliwang berdampak pada hambatan ekonomi. Selama konflik berlangsung jalur jalan Ade Irma Suryani tidak dapat dilalui oleh kendaraan, karena ditutup sementara oleh pihak keamanan. Sebagian masyarakat merasa terganggu potensi perekonomiannya, misalnya kerugian materil yang dialami oleh para pemilik rumah makan, beberapa rumah makan tutup selama konflik terjadi, seperti rumah makan padang, lesehan Ade Irma, lesehan Taliwang Raya disebabkan karena sepinya pengunjung. Demikian juga toko dan kios yang berada di sepanjang jalan Ade Irma Suryani ditutup selama konflik terjadi, daerah 
tersebut diisolir oleh pihak keamanan akibat pertikaian yang tidak kunjung usai (wawancara, Hasin, 2018).

Konflik yang terjadi mengakibatkan aktifitas masyarakat dalam melakukan pekerjaan sehari-hari menjadi terganggu. sebenarnya banyak masyarakat yang tidak menginginkan konflik ini terjadi, karena selama konflik terjadi lebih banyak memberikan kerugian ketimbang manfaat. Arogansi dan ego pihak tertentu saja yang mencoba membiarkan konflik itu terjadi. Sebagai masyarakat yang giat bekerja keras dalam menumbuhkan ekonomi keluarga dengan mata pencaharian wiraswasta dan kuli bangunan, merasa jenuh dan bosan jika aktifitas mereka dihambat. Kendati demikian, setelah perjanjian damai, menurut beberapa orang warga, kondisi perekonomian masyarakat kembali menjadi normal, masyarakat sudah mampu menjalankan rutinitas harian seperti biasa.

\section{Dampak Sosial}

Kondisi sosial masyarakat pasca konflik dapat mempengaruhi aspek-aspek yang ada di dalam masyarakat salah satunya adalah tentu saja sangat mempengaruhi pola hidup masyarakat di masing-masing kelurahan tersebut, masyarakat Monjok dan Karang Taliwang pada dasarnya selalu berusaha untuk menerapkan kehidupan yang tenang, damai, serta keakraban dan saling tolong menolong serta segala sesuatunya didasarkan atas musyawarah mufakat menjadi terabaikan, karena semestinya konflik yang terjadi di kedua kelurahan tersebut bisa diselesaikan secara damai.

Salah seorang warga mengatakan bahwa konflik Monjok dan Karang Taliwang ini sudah sering terjadi, beberapa kali sudah difasilitasi perdamaian sama pemerintah kota Mataram, tapi bentrokan masih tetap terjadi. Selama konflik berlangsung jalur jalan Ade Irma Suryani tidak dapat dilalui oleh kendaraan, karena ditutup sementara oleh pihak keamanan, warga yang berkonflik juga melarang pengendara melewati perbatasan bentrokan tersebut, ini menimbulkan keresahan sosial sehingga mengganggu warga yang bermukim di sepanjang perbatasan. Selain itu interaksi sosial warga jadi terganggu wawancara, Indra, 2018). 
Lebih dari itu, bahwa konflik yang berkelanjutan mengakibatkan keresahan sosial, masyarakat saling benci dan mendorong individu untuk melakukan tindakan kurang terpuji untuk menjatuhkan lawan, misalnya memfitnah, menghambat, dan mengadu domba. Iklim ketidakpercayaan dan kecurigaan terus berkembang dalam masyarakat, saling tidak percaya dan saling mencurigai menjadi alat yang sensitif dalam memicu pertentangan yang lebih tajam. Lebih dari itu, adanya dominasi kelompok yang mencoba memanfaatkan situasi tertentu yang kemungkinan berujung pada masalah-masalah baru.

Konflik adalah produk yang timbul dari sebuah hubungan antar individu, timbulnya konflik karena adanya sebuah perselisihan-perselisihan, sehingg untuk menyelesaikan konflik dapat dilakukan dengan cara meluruskan kembali perselisihan-perselisihan yang terjadi. Komunikasi yang baik merupakan cara yang paling utama harus dilakukan untuk menjadikan konflik yang ada bisa terselsesaikan dan terpecahkan secara baik. Oleh karena itu, diharapkan pihakpihak yang berkonflik untuk menjalani kehidupan yang damai.

\section{Analisis Resolusi Konflik Sosial Melalui Pendekatan Komunikasi}

Salah satu cara yang dapat dilakukan dalam resolusi konflik adalah melalui perumusan pendekatan komunikasi. Kendati demikian, penyelesaian konflik antara warga Monjok dan Karang Taliwang bukanlah hal yang mudah, membutuhkan banyak energi untuk dikerahkan dalam melakukan urung rembung terhadap masalah yang sedang terjadi. Konflik yang berawal dari solidaritas kelompok di dalam masyarakat Monjok dan Karang Taliwang ini cukup memberikan alasan untuk melirik aktivitas masyarakat sebagai bentuk solidaritas kelompok. Berbagai upaya dan himbauan dilakukan oleh para petinggi kota Mataram agar masyarakat dapat menahan diri dan tidak terprovokasi. Beberapa pendekatan komunikasi yang dilakukan dalam upaya resolusi konflik antara Monjok dan Karang Taliwang. Berikut ini diuraikan secara detail: 


\section{Pendekatan Komunikasi melalui Konsoliasi}

Konflik tentu ada embrio yang menjadi pemicu atau cikal bakalnya. Oleh karena itu, pemetaan konflik adalah langkah pertama untuk mengelola sebuah konflik tertentu. Tindakan ini akan membantu kedua belah pihak akan sebuah pemahaman yang lebih jelas tentang asal usul, sifat, dinamika dan kemungkinan penyelesaian konflik. Berkaitan dengan hal tersebut penting untuk mengetahui dan paham sebab mengapa konflik masih terjadi di antara kedua kelurahan. Hal ini akan membantu menjaga agar kebijakan-kebijakan yang diambil tidak akan menimbulkan konflik baru lagi karena adanya bahaya latent dalam masyarakat tersebut.

Konsiliasi merupakan cara atau teknik yang digunakan pemerintah sebagai upaya untuk mempertemukan keinginan pihak yang berselisih untuk mencapai persetujuan dan penyelesaian. Pemerintah berusaha untuk melakukan pengendalian dengan mempertemukan tokoh-tokoh masyarakat yang mewakili kedua belah pihak untuk menemukan titik temu. Sejak awal konflik ini terjadi, sebenarnya pemerintah sudah terjun ke lapangan untuk melihat kondisi masyarakat yang berkonflik dan berusaha membangun komunikasi yang baik dengan bahasa yang mudah dimengerti oleh warga, baik melalui komunikasi interpersonal maupun komunikasi kelompok dan mencatat serta mengkaji ulang keinginan-keinginan masyarakat (wawancara, Akhmad Cahaya, 2018).

Melalui konsolidasi ini, pemerintah dapat memetakan asal mula konflik, pihak yang terlibat, jumlah kerugian, serta strategi penyelesaian. Selama ini pihakpihak yang berkonflik cenderung melihat pemindahan container sampah yang dipermasalahkan dalam perspektif mereka masing-masing. Hal ini menyulitkan penyelesaian. Mestinya komunikasi yang dibangun adalah komunikasi dua arah, agar masing-masing pihak saling memahami dan tidak terjebak pada perspektif masing-masing. Perspektif individu cenderung menjebak dan keliru karena akan menyebabkan bias dan memunculkan streotipe. Dalam upaya penyelesaian konflik, seluruh aktor mendefinisikan masalah secara bersama. Hal ini akan membawa pemahaman yang lebih terukur dan tepat untuk melihat penyebab masalah. Sehingga penggalian persoalan mendasar dalam masyarakat dapat 
terpecahkan dan penumbuhan kembali kepercayaan masyarakat terhadap pemerintahan secara kredibel di mata masyarakat.

Atas dasar uraian di atas, konsolidasi merupakan proses komunikasi, dimana semua pihak terlibat dalam intensitas diskusi yang serius sebagai upaya untuk menggali informasi yang berlangsung dalam skala lokal lingkungan untuk menemukan penyelesaian konflik antara warga tersebut. Simon Fisher menjelaskan upaya konsilidasi ini adalah memberi ruang untuk berdialog dalam rangka mencari kesepakatan tentang cara penyelesaiannya, artinya pihak-pihak yang berkonflik dipertemukan untuk berkomunikasi secara langsung. Penerapan dialog disesuaikan dengan lingkungan dan budaya di mana konflik itu terjadi (SN Kartikasari dkk, 2001:96). Dengan begitu kedua belah pihak bisa lebih memahami situasi. Tercapainya kesepakatan bukan merupakan tujuan suatu dialog, tetapi yang penting adalah saling memahami. Kesinambungan konflik akibat muncul dari sikap dan tindakan anggota kelompok warga yang cenderung menyalahi aturan-aturan yang telah disepakati bersama. Sebenarnya tingkat bertahannya perdamaian tersebut bukanlah pada proses perdamaiannya atau resolusi konflik, akan tetapi lebih mengarah pada kesiapan masyarakat itu sendiri dalam menerima kondisi yang ada.

Tujuan konsiliasi untuk mencari klarifikasi tentang isu-isu atau masalahmasalah dan mencoba mencari kesepakatan tentang cara penyelesaiannya. Oleh karena itu, konsiliasi adalah salah satu alternatif yang sangat penting untuk mengetahui dan paham sebab mengapa konflik masih terjadi di antara kedua lingkungan. Hal ini akan membantu menjaga agar kebijakan-kebijakan yang diambil tidak akan menimbulkan konflik baru lagi karena adanya bahaya laten dalam masyarakat tersebut. Sehingga upaya damai yang dilakukan kedua belah pihak akan menjadi bentuk resolusi konflik yang sifatnya permanen dan bukan hanya sebatas penyelesaian konflik sesaat.

\section{Pendekatan Komunikasi Melalui Negosiasi/Musyawarah}

Negosiasi merupakan bagian penting dalam proses resolusi konflik. Dalam kasus konflik sosial yang terjadi antar warga Monjok dan Karang Taliwang 
pemerintah berperan dalam membantu menyelesaikan konflik tersebut melalui negosiasi atau musyawarah. Bentuk penyelesaian konflik melalui negosiasi ini diharapkan ada win-win solution artinya dimana kedua belah pihak sama-sama diuntungkan tidak ada pihak lain yang dirugikan. Negosiasi ini merupakan komunikasi dua arah yang dirancang untuk mencapai kesepakatan pada saat kedua belah pihak memiliki berbagai kepentingan yang sama atau kepentingan yang berbeda.

Pendekatan komunikasi dengan cara negosiasi yang dilakukan pemerintah, pihak-pihak yang terlibat dalam konflik menghasilkan kesepakatan yang memenuhi keinginan kedua belah pihak seperti pemerintah memindahkan tempat pembuangan sampah yang berada di dekat kuburan warga Monjok dan membangun tempat pembuangan sampah permanen di wilayah yang tidak jauh dari wilayah Karang Taliwang. Pemerintah juga merehabilitasi tembok kuburan warga Monjok yang dirusak oleh warga Karang Taliwang. Selain itu, pemerintah juga melakukan koordinasi dengan aparat keamanan, aparat keamanan tidak hanya melakukan patroli siaga 3 kali sehari namun juga sudah dibuatkan Pos Pantau atau Posko jaga pada wilayah tersebut guna meredam konflik yang ada demi ketentraman dan ketertiban masyarakat sekitar (wawancara, Maslandu, 2018).

Upaya negosiasi untuk menyelesaikan konflik antara warga Monjok dan Karang Taliwang merupakan jenis komunikasi langsung yang didesain untuk mencapai kesepakatan pada saat kedua belah pihak mempunyai kepentingan yang sama atau berbeda. Pola ini relevan dengan pandangan Santoso, idealnya pola komunikasi digunakan dalam proses negosiasi adalah komunikasi konvergen dan sirkuler. Menurut pola ini arus komunikasi tidak tergantung pada komunikator tunggal, siapa saja yang peduli dan berkompeten, berdedikasi dan kredibel perlu diberi akses komunikasi dan kesempatan menjadi komunikator sekaligus komunikan, tentu dengan syarat, terbuka, sopan, saling menghormati, rasional tidak emosional, sehingga pertentangan atau konflik sosial bisa berubah ke arah yang lebih sopan, beradab dan berbudaya. Modalitasnya adalah musyawarah, 
dialog, negosiasi dengan tujuan untuk mencapai kesepakatan pihak-pihak yang berkepentingan (Santoso S. Hamijoyo, 2005:165).

Pendekatan komunikasi yang digunakan dalam penyelesaian konflik antara warga Monjok dan Karang Taliwang seperti pandangan Santoso di atas merupakan interaksi komunikasi dilakukan secara demokratis, sehingga peluangpeluang aspirasi terbuka lebar. Dalam proses komunikasi yang dilakukan tidak hanya ada sumber atau penerima saja. Sumber juga penerima, penerima juga sumber dalam kedudukan yang sama dan dalam level yang sederajat. Proses komunikasi ini dilakukan ketika duduk bersama untuk membahas penyelesaian konflik, baik tokoh masyarakat, tokoh agama, tokoh pemuda duduk bersama untuk mendiskusikan permasalahan dengan saling memberi kesempatan satu sama lain mengemukakan pendapatnya. Kemudian semua pandangan atau pendapat dianalisis dan dicari format yang sesuai dengan kepentingan bersama. Dalam proses penyelesaian konflik semua pihak berbagi atau berdialog. Isi komunikasi yang disampaikan bukan lagi bersifat informasi tetapi juga bersifat persusif.

\section{Pendekatan Komunikasi melalui Mediasi}

Salah satu upaya untuk meminimalisir konflik ataupun kekerasan adalah melalui mediasi. Mediasi selama ini dipercaya mampu menjadi solusi penyelesaian konflik karena dianggap lebih demokratis dan dapat diterima dibandingkan dengan pendekatan lainnya. Mediasi meletakan pihak yang berkonflik pada posisi sama atau setara, tidak berat sebelah, tetapi pada posisi tengah atau netral. Mediasi merupakan cara menyelesaikan konflik atau pertikaian dengan menggunakan seorang pengantara (mediator). Upaya pemerintah kota Mataram untuk melakukan mediasi adalah untuk merespon tuntutan masyarakat agar pemerintah mengambil langkah konkrit sehingga konflik tidak berlarut. Mediator merancang dan memimpin diskusi serta bertindak sebagai penengah untuk memfasilitasi kemajuan ke arah penyelesaian. Dalam proses musyawarah mufakat pemerintah dan tokoh masyarakat memanggil para pelaku atau aktor dari konflik yang terjadi (wawancara, Akhmad Cahaya, 2018). 
Setelah para pihak-pihak yang berkonflik menjelaskan kasus-kasus atau penyebab konflik yang terjadi maka mediator mendapat kejelasan akan hal tersebut. Maka dalam hal ini sebagai mediator berusaha menciptakan perdamaian serta menemukan win-win solution artinya masing-masing pihak diuntungkan tidak ada pihak-pihak yang dirugikan dalam konflik antar warga Monjok dan Karang Taliwang. Dengan mediasi tersebut kedua belah pihak yang berkonflik menyetujui persyaratan yang disaksikan beberapa pihak yang telah dipanggil dan kedua belah pihak berjanji tidak mudah terprovokasi dan main massa sendiri.

Mediator hadir untuk menyediakan komunikasi yang dapat menjembatani pihak-pihak yang berkonflik. Dampak yang diharapkan dari proses komunikasi antara para mediator dengan para kelompok yang berkonflik adalah adanya pengaruh yang terjadi dari proses komunikasi intens dalam rangka mencari solusi konflik. Dampak atau pengaruh tersebut lahir secara timbal balik yang berawal dari penyampaian sebuah pesan dalam proses komunikasi yang selalu mempengaruhi melalui pengertian yang diungkapkan. Hubungan komunikasi antar manusia dilakukan karena adanya kepentingan dan kebutuhan yang sama atau karena adanya proses interaksi sosial diantara individu. Hal ini sejalan dengan pandangan Carl L. Havland dalam Onong Uchyana bahwa kegiatan komunikasi merupakan usaha mengarahkan pesan-pesan yang sengaja dilakukan kepada pihak lain dengan tujuan untuk mendapatkan perubahan yang diinginkan baik itu ide, gagasan, perasaan, maupun tindakan (Onong, 2000:3).

Efek yang diharapkan dalam proses komunikasi mediator sebagaimana pandangan Carl L. Havland di atas adalah efek yang bersifat kognitif, afektif dan konatif yang timbul pada diri seseorang atau sejumlah orang sebagai akibat dari komunikasi yang disampaikan kepadanya. Efek kognitif berkaitan dengan perubahan pikiran, misalnya menjadi tahu karena informasi atau berita, menjadi cerdas karena banyak baca buku, menjadi kritis karena sering berdiskusi. Efek afektif berkaitan dengan perubahan perasaan, misalnya menjadi gembira, bangga, sedih, terharu, marah dan lain disebabkan suatu pesan tertentu yang dikomunikasikan kepada seseorang yang dijadikan sasaran. Efek konatif berkaitan 
dengan upaya menjadikan kegiatan yang pada gilirannya menjadi tindakan atau perilaku.

Dengan demikian komunikasi yang dilakukan mediator adalah usaha persuasif untuk merubah pandangan, perilaku dan sikap dalam arti luas termasuk dalam menyelesaikan sebuah permasalahan atau sebuah konflik. Karena sejatinya komunikasi yang disampaikan secara komunikatif akan dapat mengubah sikap, perilaku, pendapat, pandangan, dan kehidupan sosial seseorang. Ini dimungkinkan karena kegiatan komunikasi bukan hanya membuat orang lain mengerti dan mengetahui (informatif), tetapi juga bersedia menerima suatu paham, keyakinan, ajakan, perbuatan atau kegiatan (persuasif).

\section{Pendekatan Komunikasi Melibatkan Stakeholders}

Selain upaya yang dilakukan di atas, upaya lainnya yang dilakukan dalam menyelesaikan konflik warga Monjok dan Karang Taliwang adalah pelibatan stakeholders karena peran stakeholders ini sangat urgen dalam penyelesaian konflik. Pelibatan stakeholders harus berpijak pada efektifitas dan efisiensi penyelesaian konflik. Masing-masing stakeholeders yang terlibat memiliki kapasitas dan kompetensi dalam penyelesaian konflik, baik secara hukum, kebijakan, budaya, sosial, dan agama. Hal ini penting dipertimbangkan karena masyarakat Monjok dan Karang Taliwang atau masyarakat Lombok pada umumnya adalah masyarakat yang religius, sehingga pendekatan agama dan pendekatan budaya bisa menjadi jalan keluar bagi penyelesaian konflik.

Pelibatan akademisi (pelaku pendidikan) dalam penyelesaian konflik ini juga perlu dilakukan. Hal ini dibutuhkan untuk keperluan dukungan riset bagi upaya penyelesaian konflik. Data-data hasil riset akademisi perlu untuk menjadi dasar dalam menyusun strategi komunikasi penyelesaian konflik sosial. Pelaku pendidikan ini harus mampu memfasilitasi jalannya perdamaian hingga tercipta resolusi konflik yang dapat bertahan lama dan mampu menjaring aspirasi masyarakat kedua lingkungan yang berkonflik. Lebih luas dapat menjadi program pendidikan masyarakat. Konflik dapat diantisipasi karena pelaku interaksi nantinya memiliki keterampilan meredam ekspresi emosi yang dapat menyulut 
kekerasan sehingga penanganan konflik tidak hanya menjadi tanggung jawab pihak ketiga yakni pemerintah dan pihak keamanan.

Alternatif lain yang dilakukan dalam penanganan konflik warga Monjok dan Karang Taliwang adalah melalui pendekatan kebudayaan atau lembaga adat. Langkah dilakukan pemerintah dalam menyelesaiakan konflik adalah dengan menggandeng budayawan. Tokoh adat dioptimalkan sebagai salah satu sarana untuk menyelesaikan konflik atau persoalan yang timbul dalam masyarakat. Di pulau Lombok, banyak dijumpai kearifan lokal dalam mengatur sistem sosial kemasyarakatan, seperti pengaturan pemerintah desa dengan berbagai lembaga adat, persubakan, keamanan, ekonomi, politik dan begitu pula kearifan lokal yang berkaitan dengan pencegahan terhadap konflik. Pola pendekatan dalam penangan konflik dengan melibatkan tokoh adat merupakan alternatif resolusi konflik yang diharapkan menjadi energi positif bagi masyarakat. Oleh karena itu, tokoh-tokoh adat dari kedua lingkungan tersebut dipertemukan, lalu dibuat kesepakatan antara masyarakat dengan majelis adat. Dukungan dari semua pihak ini, tentu dapat menciptakan perdamaian yang permanen antara kedua belah pihak. Apalagi kemudian diketahui bahwa warga kedua wilayah pada prinsipnya mau untuk berdamai.

Dalam mekanisme penyelesaian konflik Lewis A. Coser bahwa ketegangan maupun rasa permusuhan yang mendasar tetap ada di tengah masyarakat atau kelompok yang tidak terlihat atau yang bersifat laten (di bawah permukaan), solidaritas dan kekompakan yang nampak. Dalam mekanisme penyaluran konflik, ketegangan dapat terungkap melalui berbagai bentuk tindakan, baik antar pribadi maupun kelompok. Penyaluran konflik (safety valve) dapat berupa pengaturan terhadap resolusi konflik itu sendiri dari dalam masyarakat. Katup penyelamat merupakan suatu mekanisme khusus yang dipakai untuk mempertahankan kelompok dari kemungkinan konflik sosial (Poloma, Margaret M, 2004:108).

Oleh karena itu, akar permasalahan yang menjadi penyebab pecahnya konflik antar warga kedua lingkungan yang sudah diurai dengan berbagai pendekatan di atas agar tidak terulang. Pemerintah melakukan tindak lanjut 
dengan melakukan pembinaan di bidang ekonomi agar masyarakat dapat mengalihkan perhatian mereka dengan kegiatan usaha bernilai ekonomi. Seperti diungkapkan oleh salah seorang informan bahwa pemerintah melakukan pembinaan dalam bidang ekonomi kepada masyarakat terutama kepada anak-anak muda. Anak-anak muda ini dibentuk menjadi satu komunitas dan diberikan modal usaha, misalnya usaha gipsun. Tujuannya adalah agar anak-anak muda yang tadinya menganggur, dialihkan pikiran dan perilaku mereka kepada kegiatankegiatan yang bernilai positif dan memberi income bagi mereka, dengan prinsip usaha bagi hasil dan sampai saat ini kegiatan tersebut berjalan efektif (wawancara, Busyairi, 2018).

Atas dasar itu, pemerintah juga berusaha membuat kedua kelompok warga berdamai secara permanen, di mana pemerintah kota Mataram mendirikan posko keamanan terpadu. Pembangunan posko keamanan terpadu ini sebagai upaya penanganan jangka pendek. Sementara untuk jangka menengah pemerintah kota Mataram mengupayakan adanya ketersediaan ruang publik di kedua wilayah sehingga warga masyarakat memiliki aktivitas yang positif dan sering bertemu di ruang publik ini, seperti bermain bola dan kegiatan olah raga lainnya, sebagai wujud langkah praktis dalam rangka memperbaiki hubungan kedua wilayah dan menekan terjadinya konflik antara kedua wilayah.

Selanjutnya, untuk penanganan jangka panjang pemerintah kota Mataram berusaha mengimbangi dari hati masyarakat yang paling dalam dengan selalu melakukan pendekatan baik melalui komunikasi interpersonal maupun komunikasi kelompok agar rasa persaudaraan masyarakat dapat dirajut kembali. Tidak cukup perdamaian hanya di atas kertas kalau tidak didasari dengan hati. Substansi perdamaian adalah bersama menjaga komitmen untuk menciptakan keamanan lingkungan, tidak lagi mudah terprovokasi oleh berbagai kejadian yang belum jelas maksud dan tujuannya.

Dengan demikian, sinergitas berbagai elemen masyarakat dalam mengatasi masalah konflik sosial yang terjadi di Monjok dan Karang Taliwang merupakan suatu pendekatan partisipatif berlandaskan semangat kebersamaan (togetheeness, communality) dalam mengartikulasikan dan mempersepsikan sesuatu dalam 
pikiran, sikap dan tindakan, termasuk cara memecahkan masalah bersama. Konsepsi kebersamaan tersebut menentukan tujuan proses komunikasi sehingga semua pihak yang terlibat mempunyai kesempatan mempertukarkan dan merundingkan makna pesan (exchange and negotiation of meaning) menuju keselarasan dan keserasian makna bersama. Oleh karena itu, komunikasi sebagai resolusi konflik, adalah suatu keniscayaan yang absolut, karena hanya dengan komunikasilah setiap permasalahan dan pertentangan dapat diselesaikan.

\section{SIMPULAN}

Pemicu konflik yang terjadi antar warga Monjok dan Karang Taliwang karena satu sama lain tidak saling menghargai. Akar masalahnya adalah pemindahan container sampah, di mana kedua belah pihak memiliki pandangan yang berbeda-beda. Pemindahan container sampah yang menjadi akar masalah jika dilakukan koordinasi dan sosialisasi sejak awal tentu konflik tidak akan terjadi. Konflik sosial tersebut menimbulkan berbagai macam dampak yang dapat merugikan individu dan kelompok dalam masyarakat, seperti dampak psikologis, terjadi kemacetan komunikasi, secara ekonomi merugikan masyarakat dan terjadi keresahan sosial dalam masyarakat. Oleh karena itu, beberapa pendekatan komunikasi yang dilakukan dalam upaya resolusi konflik yang terjadi adalah dengan melakukan pemetaan konflik melalui pendekatan konsoliasi, negosiasi, mediasi serta pelibatan stakeholders. Berbagai pendekatan ini dilakukan untuk memberi ruang berdialog dalam rangka menyelesaikan konflik. Pola ini mampu meningkatkan hubungan individu dan kelompok semakin baik, menyamakan persepsi antar individu dan kelompok sehingga perbedaan persepsi dan pandangan sebagai faktor penyebab konflik dapat diselesaikan.

\section{DAFTAR PUSTAKA}

Arikunto, Suharsimi, Prosedur Penulisan Suatu Pendekatan Praktek. Cet. XI; Jakarta: Rineka Cipta, 1998.

Doyle Paul, Johnson, Teori Sosiologi Klasik dan Modern. University of florida. Jilid II. (Diterjemahkan oleh Robert M.z. Lawang) Jakarta: Gramedia, 1986.

Effendy, Onong Uchjana, Dinamika Komunikasi, Bandung: Remaja Rosdakarya, 2000. 
Hamijoyo, S. Santoso, Komunikasi Partisipatoris Pemikiran dan Implementasi Komunikasi dalam Pengembangan Masyarakat. Bandung: Humaniora, 2005.

Ibrahim, Syafei, Komunikasi sebagai Determinan Pengendalian Konflik Keorganisasian. Jurnal Mediator, Vol. 2- No.1-2001.

Irawan, Prasetya, Penelitian Kualitatif dan Kuantitatif untuk Ilmu-ilmu Sosial, Jakarta: DIA FISIP UI, 2007.

Kartikasari, SN. dkk., Mengelola Konflik: Keterampilan dan Strategi untuk Bertindak, Jakarta: The British Council, 2001.

Margaret, M. Poloma, Sosiologi Kontemporer, Jakarta: Raja Grafindo Persada 2004.

Muthmainnah, Siti, Peran Dakwah dalam Mengatasi Konflik-Konflik Sosial Masa Kini. Jurnal Dakwah Tabligh, Vol. 15, No. 2, Desember 2014.

Rahmat, Jalaluddin, Ilmu Komunikasi, Bandung: Rosda Karya, Bandung, 2001.

Sofiyati, Pupun dkk., Konflik dan Stress; Pengembangan dan Perilaku Organisasi, Malang: Universitas Brawijaya, 2011.

Sugiyono, Metode Penelitian Kuantitatif, Kualitatif, dan $R$ \& D. Cet. VI; Bandung: Alfabeta, 2009.

Suranto AW., Komunikasi Interpersonal, Yogyakarta: Graha Ilmu, 2011.

Wahyudi, Manajemen Konflik dalam Organisasi Pedoman Praktis bagi Pemimpin Visioner, Bandung: Alfabeta, 2008. 